\title{
H2BS1 wt Allele
}

National Cancer Institute

\section{Source}

National Cancer Institute. H2BS1 wt Allele. NCI Thesaurus. Code C162839.

Human H2BS1 wild-type allele is located in the vicinity of $21 \mathrm{q} 22.3$ and is approximately 1 $\mathrm{kb}$ in length. This allele, which encodes histone H2B type F-S protein, plays a role in antimicrobial defense responses and chromatin condensation. 